\title{
CSR Practices in Africa: A Comparative Analysis of the Carroll's Model Between Logging Companies in the Anglo-Saxon and French-Speaking Cultural Zones of Cameroon
}

\author{
Georges WANDJI ${ }^{1}$, Isaac Bernard NDOUMBE BEROCK ${ }^{2^{*}}$ \\ ${ }^{I}$ Lecturer-researcher, FSEG-University of Dschang-Cameroon \\ ${ }^{2}$ Lecturer-researcher, ESSEC-University of Douala-Cameroon and BETA-University of Strasbourg-France \\ *Corresponding Author: Isaac Bernard NDOUMBE BEROCK, Lecturer-researcher, ESSEC- \\ University of Douala-Cameroon and BETA-University of Strasbourg-France
}

\begin{abstract}
This investigation aims at examining the relevance of contingent CSR practices by adopting Carroll's model as a conceptual framework, coupled with the contextual, cultural and intercultural analyzes of the Management of Organizations in Africa (MOA). The analysis of data collected from two Cameroonian logging companies reveals a perceived difference between employees working in the logging company located in the English-speaking part of the country and those working in that established in the French-speaking zone. Findings indicate Perceived Variations of Carroll's model in the Cameroonian logging sector. Although CSR is a common subject, its practices are not the same in these companies. This distinction is being observed in that English-speaking employees and other stakeholders are attached to legal and ethical values, unlike French-speaking people anchored in philanthropy. Theoretical and managerial implications are also developed, as well as shortcomings and future research avenues
\end{abstract}

Keywords: CSR practices, sustainable performance, managerial innovation, negative externalities, developing countries, MOA.

\section{INTRODUCTION}

Faced with an increasing globalized, uncertain and complex world, large and small companies located in northern or southern countries (mostly SMEs) are more aware that commitment to sustainable development represents an innovative lever which inevitably leads to their performance (BergerDouce, 2011; Ngok-Evina, 2014).In such logic, CSR is viewed as a strategic lever which ipso facto leads to sustainable organizational performance (Branco and Rodrigues, 2006, Crane and Matten, 2004). For Porter and Kramer (2006), it is simply a source of competitive advantages for companies. Addressed under the prism of stakeholders' management (Freeman, 1984) and perspectives (Friedman, 2007; Jensen, 2001), CSR has been receiving increasing attention from researchers for several decades. This concept has been widely tackled from the stakeholder theory's perspective in order not only to identify the actors, but also, to integrate their expectations, particularly in terms of societal issues (Laarraf et al, 2015). In such context, Bonneveux and Saulquin (2009) equate CSR to a "real management issue under stakeholders' pressure ". In the same vein, Dannon et al. (2011) reveal that in a context of increasing uncertainty and complexity, "innovation is a strategic necessity" for any organization in search for performance. According to Michell, Agle and Wood (1997),Magnan et al., (1996), the ability of a manager who operates in an essentially complex environment such as the logging industry, who combines "instrumentalism and utilitarianism" of his company with many expectations of its stakeholders, represents an emerging concern for organizational performance (Hollnagelet al., 2009). While a range of literature seems to enhance Carroll's model (1991) and support its relevance which would be adapted nec varietur in all contexts, research focusing on the relevance of contingent CSR practices, specifically in Cameroon, still remains very mitigated (Visser, 2005; Golli and Yahiaoui, 2009). Thus, in line with the above, this research aims at examining the relevance of contingent CSR practices by adopting Carroll's $(1979,1991)$ model as conceptual framework coupled with the contextual analyses' frameworks of Pettigrew (1990), Jonhson's (1992) cultural framework and the intercultural framework of the management of organizations in Africa 
from Tidjani and Kamdem (2010). This study is carried out in two Cameroonian companies operating in the logging industry which one is based in the Anglo-Saxon cultural zone (BETA) and the other in the French-speaking cultural zone (ALPHA) in Cameroon. The refutability of Carroll's model is not the purpose of this research. On the contrary, we try to support, following Visser (2005) and Ndoumbe Berock (2017), the relativity of this model by mobilizing very specific contexts: CSR in the African context where it is viewed as a constraint for organizations (Ndoumbe Berock et al., 2016). Thus, empirical research specific to this sector should reveal a hierarchy of CSR dimensions different from that of Carroll's (1991) model. In this regard, we formulate our basic postulate as follows: If it is true that CSR is a common subject, its practices are not the same in all companies in the Cameroonian logging industry because of their profiles' diversity (certified and non-certified companies) as well as their nationality which is quite different.

To achieve the purpose of this investigation, we will first focus on explaining the theoretical anchoring of this research, then the adopted methodology, including a qualitative one based on a multiple case study of two companies in the Cameroonian logging industry which one is based in the "French-speaking" zone and the other in the "English-speaking" zone of the country. Finally, we will discuss our results and present their managerial implications.

\section{CSR AND STAKEHOLDER THEORY}

\subsection{CSR Theoretical Foundations}

CSR is receiving increasing attention in both academic and business circles. This concept both refers to ethical and moral concerns likely to impact not only decision-making, but also, corporate behavior. According to Branco and Rodrigues (2007), the CSR concept has raised an important issue, that relating to the need for a company to internalize or not the negative externalities of its activities on society. In this logic, these authors argue that corporate actions disconnected from the pressures exerted by stakeholders which are part of the logic in line with the conservation of natural resources and/or preservation of biodiversity are morally commendable (Branco and Rodrigues, 2007). In the same vein, Valor (2005) specifies that CSR is a "trigger alert" concept to managers, reminding them that the pursuit of profit and social considerations are not dissociable. It is probably for this reason that Maclagan (1998) argues that CSR strives to "identify and satisfy the interests of those affected by corporate actions". Similarly, Valiorgue (2016) simply equates CSR to a strategy adopted by companies to "internalize the negative externalities of their activities". Sharma (2001) also specifies that any company which embarks on CSR's path ipso facto fits in a logic of "arbitration between an increase in its economic performance, a reduction of ecological damage and a search for social justice". This CSR apprehension goes in line with the European Commission's (2001) vision that"being socially responsible not only means to fully comply with the applicable legal obligations, but also, to go beyond and invest more in human capital, environment and relationships with stakeholders ".

However, some theses not fully agree with CSR purpose. For some authors like Porter and Kramer, (2007) and Hart and Prahalad, (2002), CSR is both a source of competitive advantages and strong economic opportunities for the company. On the other hand, for some scholars including Friedman (1970) and Levitt (1958), CSR is only a source of expenditure and consequently, it has a strong negative impact on profitability and even corporate performance. Referring to the reality field, some managers seem to adhere to CSR'svirtues by allocating a budget to social and environmental activities. Others go further by changing their corporate configuration and creating a new CSR headquarters, department or service. This increased corporate interest in CSR highly demonstrates the recognition of their stakeholders' legitimacy. This is undoubtedly what stimulates Branco and Rodrigues (2007) to highlight on a "positioning of the stakeholder theory in the debate on Corporate Social Responsibility".

A range of literature on this concept shows that several theories, including the agency theory, the contract theory, the new institutional theory and the governance theory, just to name the few, are likely to be mobilized in works in line with the CSR concept (Gond and Mullenbach, 2004). However, our postulate in this article lies on that the running (Mullenbach-Servayre, 2007) of CSR specifically highlights the corporate responsibility towards its stakeholders in order to maintain its social 
cohesion. Following such logic, the stakeholder theory (Freeman, 1984; Clarkson, 1995; Mitchell et al., 1997; Rowley, 1997) seems to be imposed in our context, particularly to better understand and analyze the concerns related to perceptions that stakeholders have in CSR practices in companies as far as the Cameroonian logging industry sector is concerned.

It is certainly in this regard that Gendre-Aegerter (2008) likens the stakeholder theory to the theoretical basis of different themes related to CSR. This author strongly argues that "the CSR concepts and stakeholder are intimately or conceptually related" (Gendre-Aegerter, (2008).) In such logic, it is not conceivable to appeal to the responsibility notion without referring to either an individual or a group of individuals for whom we feel fundamentally responsible (Gendre-Aegerter, 2008).That's why we are interested in analyzing stakeholders' perceptions towards Cameroonian logging companies and many relationships they have with these companies. This approach seems important for us to justify the various social and environmental strategic orientations of these companies.

This is probably what justifies the position of Ackermann and Eden (2003) for whom "paying attention to stakeholders is likely to have noticeable effects on the running of CSR strategies in companies". However, some authors like Clarkson (1995), Mitchell et al. (1997), Sethi (1995) and Rowley (1997) emphasize that stakeholders'management will depend on their position towards the company (Oliver, 1991; Clarkson, 1995). Mitchell et al., 1997; Sethi, 1995; Rowley, 1997). Referring to companies studied and based on the contextual analysis of Pettigrew (1990), the cultural analysis of Jonhson (1992) and the intercultural analysis of the Management of Organizations in Africa (MOA)Tidjani and Kamdem (2010), we postulate that the perceived CSR practices by stakeholders ina company located in the English-speaking part of the country are not the same as thoseperceivedby stakeholders in a company based in the French-speaking area. In other words, the perceived CSR practices by managers will differ not only from those of employees, but also, from those of the neighboring communities and the administration in charge of the logging issues. With all this in mind, it is therefore clear that the perception of Carroll's model as concerns CSR differs depending on actors. Therefore, this model is contingent to the Cameroonian logging sector context.

\subsection{Carroll's Model (1979,1991): Contingent CSR Practices}

Varied literature brings out a debate not only on the definition of CSR, but also, on its issues, purpose and modeling (Gond and Mullenbach, 2004). Specifically speaking, these debates put into perspective the relationship between the corporate world and society as a whole, and more especially, the juxtaposition of shareholders' and stakeholders' interests (Branco and Rodrigues, 2007). Though considered as an unclear concept by Christine Noël (2004), it is clear that this concept is usually used to show that other groups apart from shareholders are also affected by these corporate activities and therefore deserve to be taken into account in managers' concerns (Werhane and Freeman, 1999).

Taking a stand on these debates, Beckman et al. (2007) defined CSR by referring to corporate obligations towards the society, and particularly with regard to their stakeholders, that is, those "who are likely to affect or be affected by the corporate policy and practices " (Freeman, 1984). That's why Smith (2003) probably supports the idea that "companies are becoming more aware of their responsibility and are beginning to integrate these obligations, particularly in the philanthropic and environmental domains while taking into account the ethical and economic business aspects". Mercier (2004) acknowledges the remarkable contribution of Carroll (1979) in literature on CSR. Indeed, he proposes a definition which gathers "all corporate economic, legal, ethical and discretionary obligations with regard to the society"(Mercier, 2004). For Carroll (1979), the fact that a company creates wealth while complying with regulations is a fundamental aspect which allows understanding that the latter incorporates ethical and societal values as a priority. In addition to the lack of consensus on CSR definition (Frederick, 1986; Sethi, 1975 and 1979; Clarkson, 1995), the modeling of this concept and its approximation to some concepts such as ethics and performance has been a hindrance to both its understanding and emergence (Carroll, 1999). Despite the above- mentioned obstacles to the emergence of this concept, some authors including Wartick and Cochran (1985), Oliver (1991), Carroll (1991), Wood (1991) and Mitchell et al. (1997) are more concerned to propose models which are both divergent and convergent with the aim of illuminating the CSR concept. Among these models, that proposed in two phases (1979 and 1991) by Carroll and known by many scholars to be 
the most relevant in research on CSR (Golli et al. Yahiaoui, 2009) has most caught our attention. In his model, the author acknowledges that economic responsibility is the most important reason for the running of any company. However, he recognizes and integrates other forms of responsibilities, including the legal, the ethical and the philanthropic which are, according to him, equally important to achieve corporate performance (Saghroun and Eglem 2008). This model, perceived by many authors as simple, precisely in the understanding of CSR, is presented in the form of a pyramid. It supports the idea that economic responsibility is the platform on which the legal, ethical and philanthropic responsibilities of every company all depend (Pinskston and Carroll, 1996). For Carroll (1979, 1991), each of these responsibilities represents a component of the overall responsibility of any corporation.

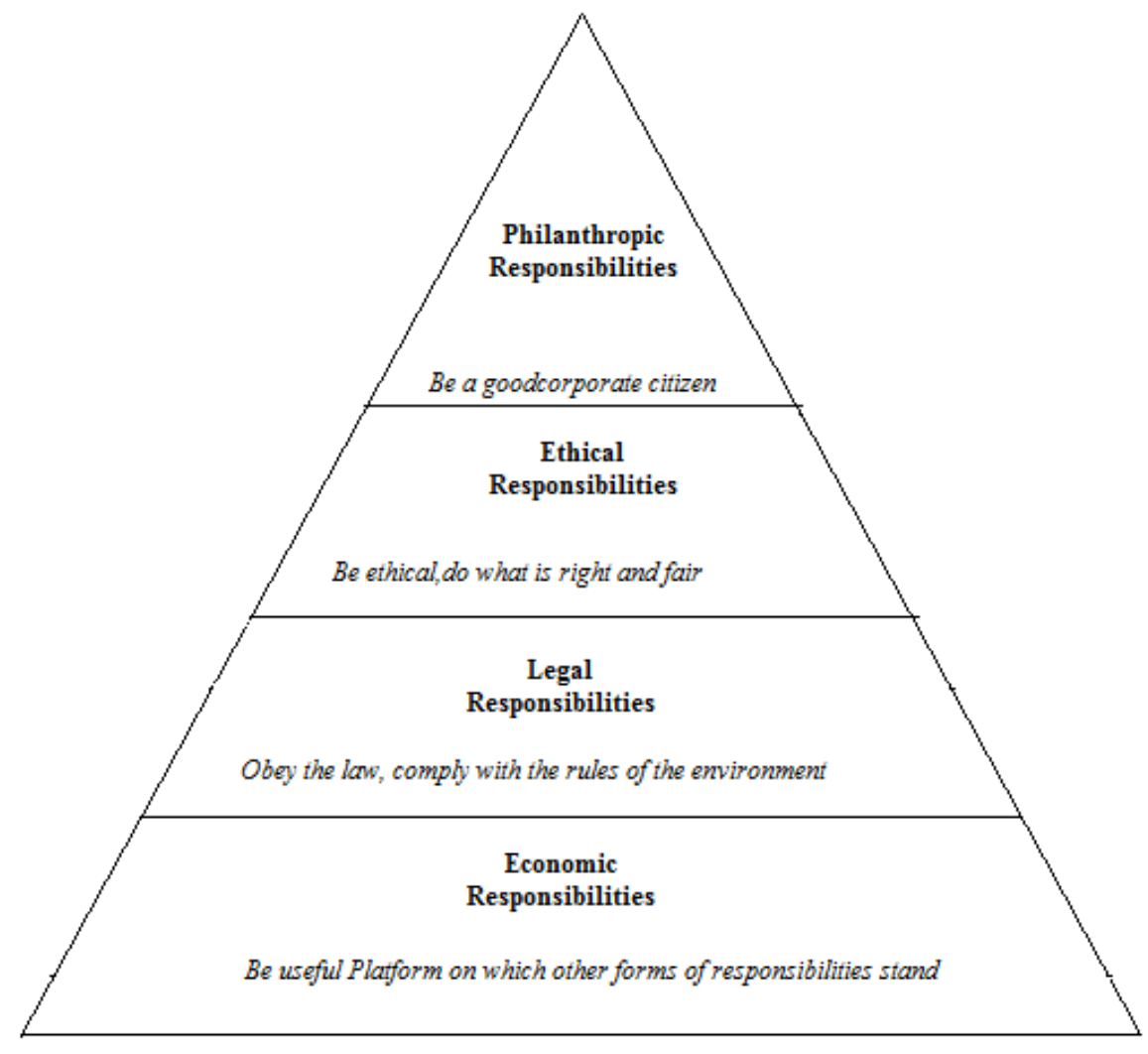

Figure1: Carroll's $(1979,1991)$ pyramid on CSR

Source: Carroll $(1979,1991)$.

\section{Contextual, CUltural AND inTERCUltural ANALysis FramewORK OF THE MANAGEMENT OF ORGANIZATIONS IN AFRICA (MOA)}

Many investigations have long overshadowed the historical and procedural aspect of organizational transformation which is nevertheless very important. This failure was remedied by the development of the contextual approach by Pettigrew (1987, 1990 and 1992). This approach, according to Talbot and Turgeon (2010), aims at explaining not only the mechanisms, but also, the process inherent to organizational change. In the same vein, Schäfer (2016) strongly reveals that the adherence and implementation of CSR practices essentially have a catalytic effect on organizations and stimulate them to opt for change. This author highlights that commitment to CSR values by epiphenomena, especially green washing, produces very little changes because they are solely confined to the improvement of both reputation and organizational legitimacy (Schäfer, 2016). Unlike other standards, Schäfer (2016) considers that CSR encourages companies to adopt and develop innovative practices (Berger-Douce, 2011). For Talbot and Turgeon (2010), adherence to CSR principles is likely to implicitly engage companies on the path of radical change. Thus, by associating the contextual framework of Pettigrew $(1987,1990,1992)$ to the cultural analysis (Jonhson, 1992) and the intercultural analysis of the Management of Organizations in African (Tidjani and Kamdem, 2010), we admit that if CSR stands out as a common subject for companies specifically those in Cameroonian logging sector, its implementation is not necessarily done in the same way in all these organizations, given their cultural (companies with Anglo-saxon culture and those with French- 
speaking culture) and intercultural (companies located in English-speaking or French-speaking parts of the country)diversity, the strategy adopted (precursor, pragmatic or follower), their commitment or not to forest certification, the origin of their capital (foreign or local firms), etc. Thus, following some authors, notably Talbot and Turgeon (2010), we wish through this work to help overcoming the insufficiency of empirical research on contexts' receptivity. A major contribution of Pettigrew's contextual approach (1987, 1990 and 1992) lies in the superimposition of three concepts namely the context, the content and the necessary process to apprehend organizational change.

Table1: Concepts of Pettigrew's Contextual Approach (1987, 1990, 1992)

\begin{tabular}{|l|l|l|}
\hline Concept & Question & Inquiry \\
\hline Content & What & What changes? \\
\hline Context & Why & Which variables influence thechange process? \\
\hline Process & How & How was the change process? \\
\hline
\end{tabular}

Source: Adaptedfrom Pichault, 2003, p.1754.

The first dimension noted in Pettigrew's contextual approach (1987, 1990 and 1992) refers to the content, that is, the "what"? This dimension is based on different domains concerned by the transformation mechanisms. The context is subdivided into two very distinct components, namely the internal and external environments. The external context close to cultural and intercultural analyses refers not only to the socio-economic, political, cultural environment, but also, to the legal, technological and geographical environment of the organization. On the other hand, the internal environment refers to the culture, structure and identity of the company. The third and last dimension of the analysis framework developed by Pettigrew concerns the change process. This last dimension is based on the temporal deployment of change. It integrates the actions and interactions of actors likely to move the company from an initial "Phase A" to a more innovative and adapted "Phase B". This is undoubtedly what leads Acquier (2007) to point out that "CSR highlights values and practices of companies that have voluntarily committed themselves to it ". Following such logic and depending on their appropriation degree, CSR can bring a cultural change within the company in general and more particularly within companies in the Cameroonian logging sector.

\section{EXPLORATORY STUDY OF CARROLL'S MODEL (1979) IN CAMEROONIAN LOGGING COMPANIES}

The interpretive orientation of this work on CSR in the Cameroon logging sector strongly takes into account a qualitative approach based on a multiple case study (Yin, 2003). We will first present our methodological approach (2.1) followed by data collection and analysis (2.2).

\subsection{Research Methodology}

Our phase of data collection and analysis aims at essentially generating highly contextualized knowledge. It is based on view points and even actors' perception, particularly on four essential stakeholders of our research field (managers, employees, local and riparian communities and logging administration) which constitute the logging sector in Cameroon (idiosyncratic and empathic characters) . Thus, the epistemological aspect of "interpretative" type is proven to be the most adapted for this research insofar as it favors the opinion of Collerette (1996 and 1997), the understanding and analysis of the reality of things as they are not only perceived, but lived by actors in this sector in an essential exploratory approach. Following such logic, the qualitative approach based on a multiple case study (Yin, 2004 and Miles and Huberman, 2003) adopted in this work finds all its meaning both in the specificity of the application field and in the research objective. This investigation focuses on the relevance of Carroll's model (1979 and 1991) to understand, from a comparative perspective, CSR practices in Cameroonian logging companies, based on two cases in different geographical and cultural contexts: the English-speaking area (very seasoned with claims and protest) and the Frenchspeaking area of the country (very passive and submissive). These companies are therefore called in view of these socio-cultural and linguistic differences (English and French) to implement differentiated CSR practices. In this regard, we used Pettigrew's contextual analysis framework (1987, 1990 and 1992) associated with the cultural approach (Jonhson, 1992) and that of the intercultural management of organizations in Africa (Tidjani and Kamdem, 2010) to understand the relevance of Carroll's model on companies in the Cameroonian logging industry. Finally, we opted for two certified cases, including one Dutch company (located in the English-speaking part of the country) and one French company (located in the English-speaking part of the country). 


\subsection{Data Collection}

We opted for a multiple case study in this research. Its particularities are not only to identify, but also, to emerge recurring elements between cases, after conducting an in-depth analysis of each case associated to its specificities (Yin 1994, Collerette 1996). Within the framework of this research, we limited ourselves to two cases (Eisenhardt, 1989, Yin, 1994): the "Alpha" company and the "Beta" company. We used the opportunity principle to make a convenient sample, relying on the high position of one of our relatives (Official in the Ministry of Forests) to "instigate" these companies to partner with us.

The choice of the studied cases was motivated by that they have distinctions and specificities likely to enrich the analysis of the perception of the targeted actors in relation to CSR practices in logging companies. These cases are both subsidiaries of multinationals and are all FSC-certified companies. In addition, while Alpha is specialized in logging and marketing, Beta is specialized in logging, wood processing and log marketing. We also used data from literature review (nearly 100 documents used), semi-structured interviews (with internal and external stakeholders) and direct observations over a period of two months in the study field, with one month per company between March and April 2015. This compulsory triangulation of data source was very important to our research. During data collection, we interviewed thirty-four people, including eighteen external correspondents from Alpha and thirty-seven people, fifteen of whom were external from the Beta Company. Among those interviewed within these companies, we have, among others, managers and / or site managers, service managers, staff representatives and some employees with at least 20 years of work experience in the company. Externally, we had interviews with village chiefs in the logged forests, administrative authorities (SDO and DO), departmental delegates of labor and social welfare, departmental delegates of water and forests, departmental delegates of environment and some elites (deputies or substitute deputies) (see Table 2). At the end of the interviews, it was ensured that the theoretical saturation in line with Strauss and Corbin (1990) was reached. We used interview guides which included topics related to Carroll's (1979and1991) models on CSR. Interviews were conducted for one hour and a half per respondent. For confidentiality sake desired by almost all interviewees, we only based ourselves on notes taken during interviews to retranscribe them for better use.

Data processing and analysis was done in several stages. We first formulated cases, and then proceeded to the analysis of each of them before concluding by the transversal analysis of these cases. This approach resulted in the transition from a degree of descriptive comprehension to a higher degree of abstraction which, according to Collerette (1996), "involves the analysis and explanation likely to grasp the links between the reported events ". Case study was done according to Gagnon (2008) by processing and analyzing data from interviews and observations made in each context.

After completing interviews and observations, we prioritized the material preparation phase by setting up the corpus and writing the interview verbatim. The second stage was devoted to reading the verbatim to impregnate ourselves with the collected material and especially to make a pre-analysis. This step led not only to set up the categorical system, but also, to choose the segmentation units prior to coding. Finally, we carried out a content analysis followed by a cross-sectional analysis of cases in order to bring out the convergent and divergent aspects (Miles and Huberman, 1991).

Table 2 below gives an overall synoptic presentation of the two companies (cases) studied.

Table2: Synoptic Presentation of studied cases

\begin{tabular}{|l|l|l|l|l|l|l|l|}
\hline Companie & Activities & $\begin{array}{l}\text { Work } \\
\text { experience } \\
\text { and status }\end{array}$ & $\begin{array}{l}\text { Harvested } \\
\text { area (in } \\
\text { hectare) }\end{array}$ & Certificate & $\begin{array}{l}\text { CA }^{\mathbf{1} 2013} \\
\text { and } \\
\mathbf{2 0 1 4}\end{array}$ & $\begin{array}{l}\text { Number } \\
\text { of emplo } \\
\text { yees2015 }\end{array}$ & $\begin{array}{l}\text { Turnover } \\
\text { Structure }\end{array}$ \\
\hline ALPHA & $\begin{array}{l}\text { Logging, } \\
\text { Marketing }\end{array}$ & 44 years & 388.949 & $\begin{array}{l}\text { FSC } \\
\text { Certified }\end{array}$ & $\begin{array}{l}8.28 \text { and } \\
9.968\end{array}$ & 350 & $100 \%$ French \\
\hline BETA & $\begin{array}{l}\text { Logging, } \\
\text { Processing, } \\
\text { Marketing }\end{array}$ & 14 years & 70.298 & $\begin{array}{l}\text { FSC } \\
\text { Certified }\end{array}$ & 8 and 8.7 & 277 & $\begin{array}{l}65 \% \text { Dutch } \\
\text { and } \begin{array}{r}35 \% \\
\text { Cameroonian }\end{array}\end{array}$ \\
\hline
\end{tabular}

Source: HR services, certification and accounting of the companies studied

${ }^{1}$ The essential declarative turnover is in billions of CFA Francs. 
CSR Practices in Africa: A Comparative Analysis of the Carroll's Model Between Logging Companies in the Anglo-Saxon and French-Speaking Cultural Zones of Cameroon

\subsection{Data Analysis: Content Analysis and Matrix Presentation of Verbatim.}

Using the contextual analysis framework of Pettigrew (1987, 1990 and 1992) coupled with the Johnson's (1992) cultural analysis and the intercultural approach of the Management of Organizations in Africa, interviews with the main actors in the Cameroonian logging sector (Managers of the two companies, their staff, the local and riparian communities and the logging administration officials) are recorded in the analysis grid below set up with reference to Carroll's model $(1979,1991)$.

Table3: Perception or prioritization of CSR practices by the main actors in the logging industry in Cameroon

\begin{tabular}{|c|c|c|c|c|c|c|c|c|}
\hline $\begin{array}{l}\text { ALPHA } \\
\text { and CSR } \\
\text { dimensions }\end{array}$ & Manager & $\begin{array}{l}\text { Ran } \\
\mathbf{k}\end{array}$ & Employees & $\begin{array}{l}\operatorname{Ran} \\
\mathbf{k}\end{array}$ & $\begin{array}{l}\text { Local and riparian } \\
\text { Communities }\end{array}$ & $\begin{array}{l}\text { Ran } \\
\mathbf{k}\end{array}$ & $\begin{array}{l}\text { Administration } \\
\text { in charge of } \\
\text { logging issues }\end{array}$ & Ran \\
\hline Economic & $\mid \begin{array}{lr}\text {-Search for } & \text { profit } \\
\text {-Integration } & \text { of } \\
\text { other } & \text { aspects } \\
\text { (social) } & \end{array}$ & & \begin{tabular}{|lr}
-Improve & our \\
living and our \\
professional \\
conditions \\
-Search r for \\
profit r \\
- Economic and \\
social aspects \\
are indissociable
\end{tabular} & & \begin{tabular}{|lr}
-Search for & profit, \\
-Integration & of \\
residents' & concerns \\
-Sign a specification
\end{tabular} & & $\begin{array}{l}\text {-Need to always } \\
\text { make profit } \\
\text {-Respect of the } \\
\text { institutional } \\
\text { framework }\end{array}$ & \\
\hline Legal & $\begin{array}{l}\text {-Importance } \\
\text { granted to the } \\
\text { social component } \\
\text {-Conformity to the } \\
\text { context's } \\
\text { requirements }\end{array}$ & & $\begin{array}{l}\text {-Require the } \\
\text { right to operate } \\
\text {-To adapt to the } \\
\text { context } \\
\text {-The law comes } \\
\text { in third position }\end{array}$ & & $\begin{array}{l}\text {-Signand respect the } \\
\text { specifications } \\
\text {-Compliance with } \\
\text { commitments }\end{array}$ & & $\begin{array}{l}\text { - Respect of the } \\
\text { institutional } \\
\text { framework } \\
\text { Respect } \\
\text { agreements } \\
\text {-Priority to the } \\
\text { legal aspect }\end{array}$ & \\
\hline Ethical & $\begin{array}{|ll|}\text { The ethical and } \\
\text { legal aspects } \\
\text { linked }\end{array}$ & & $\begin{array}{|lr|}\text { Ethics } & \text { and } \\
\text { Laware } & \text { in } \\
\text { dissociable } & \\
\end{array}$ & & $\begin{array}{|lr|}\text {-Ethics is ronfused } \\
\text { with the regal } \\
\text { framework }\end{array}$ & & $\begin{array}{l}\text {-Ethics is linked } \\
\text { to law }\end{array}$ & \\
\hline $\begin{array}{l}\text { Philanthrop } \\
\text { ic }\end{array}$ & 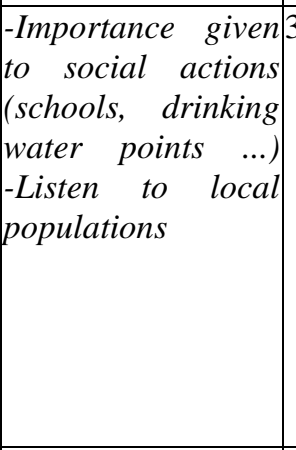 & & $\begin{array}{l}\text {-Medical health } \\
\text { insurance for } \\
\text { families } \\
\text {-Requestfor } \\
\text { benefits in kind } \\
\text {-Support retired } \\
\text { employees with } \\
\text { dignity } \\
\text {-Priority to the } \\
\text { philanthropic } \\
\text { aspect }\end{array}$ & & 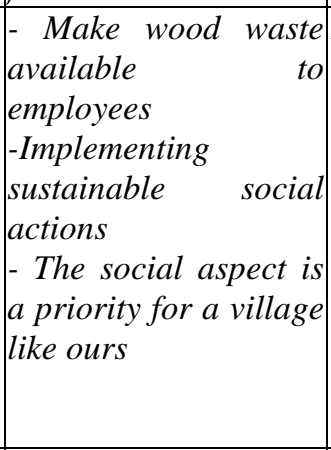 & & \begin{tabular}{|lr} 
& To \\
concerned & be \\
socialissues \\
-Release a part \\
of its profits for \\
social r issues \\
- The law does \\
not take it into \\
account
\end{tabular} & \\
\hline $\begin{array}{l}\text { BETA and } \\
\text { CSR } \\
\text { dimensions } \\
\end{array}$ & \begin{tabular}{|l|l} 
Manager & $\mathbf{F}$ \\
\end{tabular} & $\begin{array}{l}\text { Ran } \\
k\end{array}$ & Employees & $\begin{array}{l}\text { Ran } \\
\mathbf{k}\end{array}$ & $\begin{array}{l}\text { Localand riparian } \\
\text { Communities }\end{array}$ & $\begin{array}{l}\operatorname{Ran} \\
\mathbf{k}\end{array}$ & $\begin{array}{l}\text { Administration } \\
\text { in charge of } \\
\text { logging issues }\end{array}$ & Ran \\
\hline Economic & \begin{tabular}{|l}
-Priority to our \\
Business \\
-Whenever it is \\
possible and then \\
see the other \\
aspects
\end{tabular} & & $\begin{array}{l}\text {-The company is } \\
\text { there for profit } \\
\text { - Employees are } \\
\text { the makers of } \\
\text { this profit The } \\
\text { lompany } \\
\text { therefore has the } \\
\text { obligation to } \\
\text { encourage us so } \\
\text { that we should } \\
\text { always be more } \\
\text { fruitful } \\
\text {-Prioritize the } \\
\text { makers of this } \\
\text { profit }\end{array}$ & & $\begin{array}{l}\text {-Hinder } \\
\text { activities 'boycott } \\
\text { - Take into account } \\
\text { the } \\
\text { residents'problems }\end{array}$ & $2^{\text {nd }}$ & $\begin{array}{l}\text { - Conform to the } \\
\text { institutional } \\
\text { framework in } \\
\text { which } \\
\text { operates. }\end{array}$ & \\
\hline Legal & $\begin{array}{l}- \text { The respect of the } 2 \\
\text { regulation }\end{array}$ & & $\begin{array}{lr}- \text { Respect } \\
\text { agreements }\end{array}$ & & $\begin{array}{l}\text { - Respect the law and } \\
\text { regulations }\end{array}$ & & $\begin{array}{l}\text { The legal aspec } \\
\text { important }\end{array}$ & \\
\hline
\end{tabular}


CSR Practices in Africa: A Comparative Analysis of the Carroll's Model Between Logging Companies in the Anglo-Saxon and French-Speaking Cultural Zones of Cameroon

\begin{tabular}{|c|c|c|c|c|}
\hline & $\mid \begin{array}{l}\text { fundamental } \\
- \text { We are required to } \\
\text { respect local } \\
\text { institutions } \\
\text {-The legal aspect } \\
\text { follows economic } \\
\text { objectives }\end{array}$ & $\left|\begin{array}{l}\text { law } \\
\text {-Respect } \\
\text { operating rules } \\
\text { governing the } \\
\text { business sector }\end{array}\right|$ & \begin{tabular}{|l}
-The law has planned \\
everything \\
-Corruption \\
authorities \\
-Respect of the \\
specifications
\end{tabular} & \begin{tabular}{|l}
- Respect of the \\
commitments of \\
the country on the \\
international scale \\
(conservation on \\
the biodiversity). \\
Companies must \\
respect r it \\
- The legal aspect \\
is more important
\end{tabular} \\
\hline Ethical & $\begin{array}{l}\text {-The respect of law } \\
\text { is more important } \\
\text {-Improve } \\
\text { relationships with } \\
\text { local residents }\end{array}$ & $\begin{array}{l}\text {-The ethical } 1^{\text {st }} \\
\text { aspect is less } \\
\text { important } \\
\text { - Sufficient law } \\
\text { enforcement } \\
\text {-Ethics is the } \\
\text { same as law }\end{array}$ & $\begin{array}{l}\text {-Respect of the } 1^{\text {st }} \\
\text { specifications }\end{array}$ & $\begin{array}{l}- \text { Ethics } \\
\text { to } \\
\text {-The linked } \\
\text { its cospect of } \\
\text { its } \\
\text { is fundamitments } \\
\text { stal }\end{array}$ \\
\hline \begin{tabular}{|l|} 
Philanthrop \\
ic \\
\\
\end{tabular} & $\begin{array}{l}\text { "We operate in the } 3^{r a} \\
\text { English-speaking } \\
\text { part of the country } \\
\text { - Populations here } \\
\text { are more awake } \\
\quad \text {-Always on the } \\
\text { offensiver } \\
\text {-We make efforts to } \\
\text { meet their } \\
\text { expectations with the } \\
\text { (compliance wifications) } \\
\text { specific }\end{array}$ & 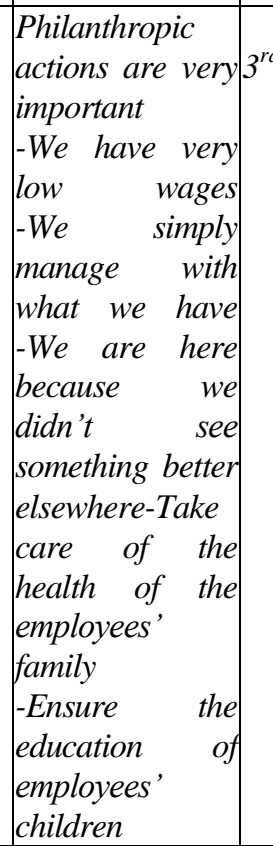 & $\mid \begin{array}{lrr}- \text { The } & \text { withdrawal of } \\
\text { our } & \text { resources } & \text { causes } \\
\text { us a } & \text { lot of } & \text { harms } \\
- \text { We } & \text { are } & \text { very } \\
\text { demanding } & \text { towards } \\
\text { crooked } & \text { companies } \\
\text {-Improving } & \text { our living } \\
\text { conditions } & \end{array}$ & $\begin{array}{l}\text { - Companies are } 3^{\mathrm{r}} \\
\text { under pressure } \\
\text { from } \\
\text { employees } \\
\text {-Taxes to pay, } \\
\text { etc... } \\
\text {-It is up to the } \\
\text { State to take care } \\
\text { of the social } \\
\text {-Freeto engage } \\
\text { or not in } \\
\text { philanthropy }\end{array}$ \\
\hline
\end{tabular}

Source: Extract from the interviews with the main actors in the Cameroonian logging sector

\section{Presentation OF ReSEarCh FINDINGS}

Based on literature review, we set up an analysis grid. We exploited the work of Crane and Matten (2004), Visser (2005); Fadun (2014); Kwasi and Kwesi (2011); Golli and Yahioui (2009) and Zabin (2013) to identify the themes of the grid. All these investigations aimed at studying the relevance and reliability of Carroll's model to understand CSR practices in companies. The perception of the main actors of the two companies located in the English-speaking (BETA) and French-speaking (ALPHA) parts of Cameroon was analyzed.

\section{COMPARATIVE ANALYSIS}

The comparative analysis between the CSR practices in the company with an English-speaking culture located in the English-speaking part of the country and those with the French culture company based in the French-speaking zone of the country show similarities, but also, differences between the two groups. Findings obtained in Table 3 on stake holders' perceptions of the CSR concept show that "the pre-eminence of the economic aspect over other elements of Carroll's model" is a common feature between the two companies' managers. The role of employees is also identified as essential for the two managers to engage themselves in CSR, which seems to converge with the idea of a social interpretation of CSR in line with Hassine and Ghozzi-Nékhili (2013). Findings on ethical and legal aspects of Carroll's model of CSR which underline "a confusion of these two elements by the actors interviewed" is a common point to be noted. These results also reveal that the environmental 
dimension is a major concern for managers of both companies, which justifies their behavior as FSC certified companies, identified through the management and recycling of waste, forest management, energy consumption reduction through the use of low-impact machines.

Some differences also exist. They are particularly related to the priority given to the respect of law and ethics essentially present among employees and local and riparian communities of the company based in the English-speaking part of the country. On the other hand, if the social or philanthropic aspect seems to hold the attention of managers of these companies, findings reveal that the social or even philanthropic aspect is more worrying for employees and for local and neighboring communities of the company located in the French-speaking part of the country, unlike employees and local and neighboring populations of the company established in the English-speaking part of the country who are more concerned with legal and ethical aspects. They put more emphasis on the law concept respect and commitments made by the company during the tripartite opening ceremony of the Annual Logging Stand (ALS) between the representatives of the company, the local and riparian communities as well as the local administration. Commitment to international standards has no impact on the CSR ownership of interviewed managers. To this effect, the adoption of these standards like ISO 14001, OHSAS 18001 and ISO 9001 is considered a truly independent action which is neither part of the overall CSR strategy nora discriminating criterion in the perception of CSR. The figures below summarize the variations of Carroll's model as perceived by the different stakeholders interviewed.

Company located in the Anglo-Saxon Zone CSR model from BETA Manager

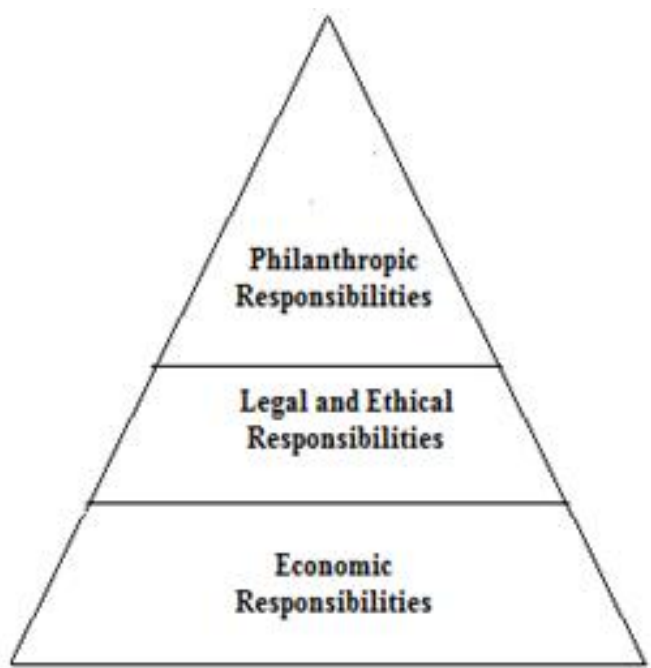

CSR model from employees of BETA

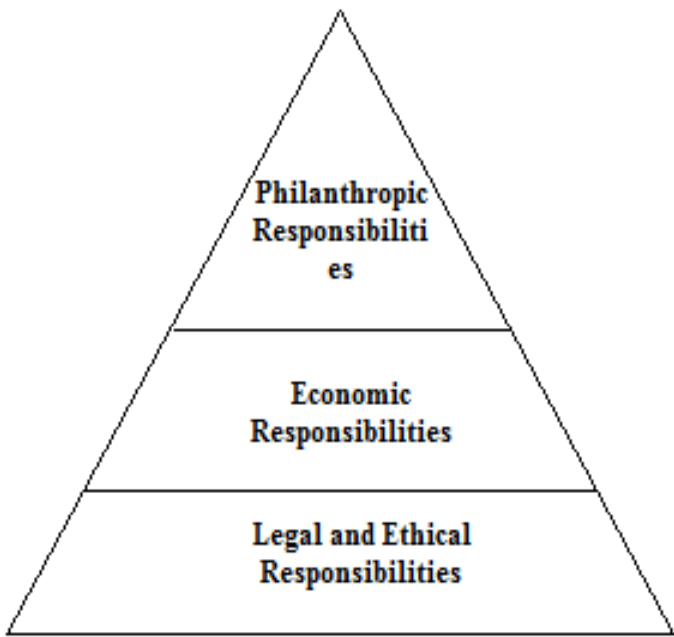

CSR model from local and neighboring communities of BETA

\section{Company located in the French-speaking zone} CSR model from ALPHA Manager

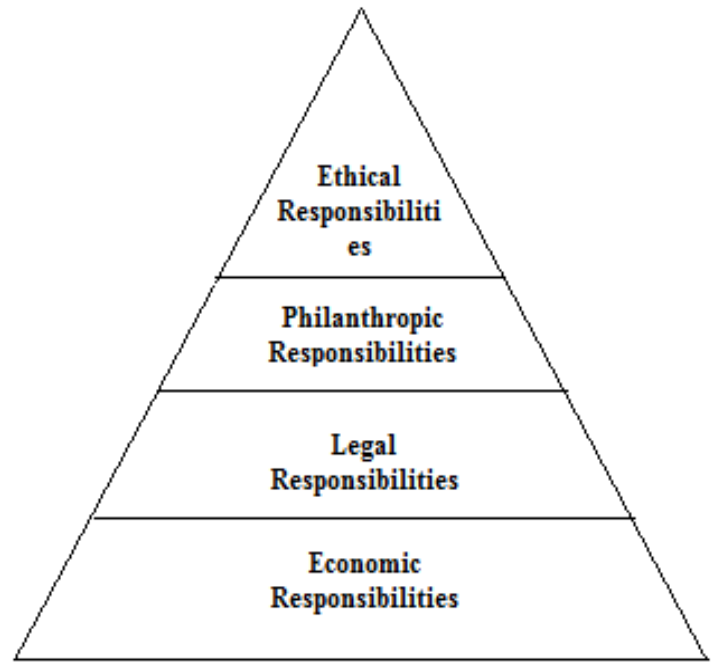

CSR model from employees of ALPHA

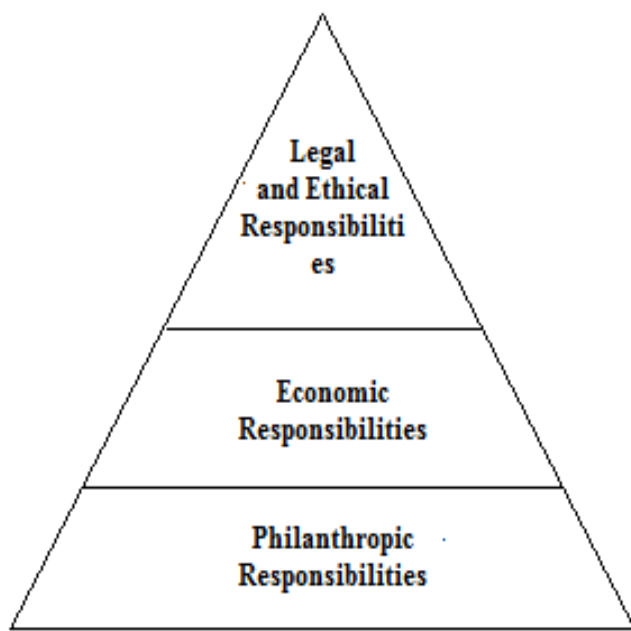

CSR model from local and neighboring communities of ALPHA 

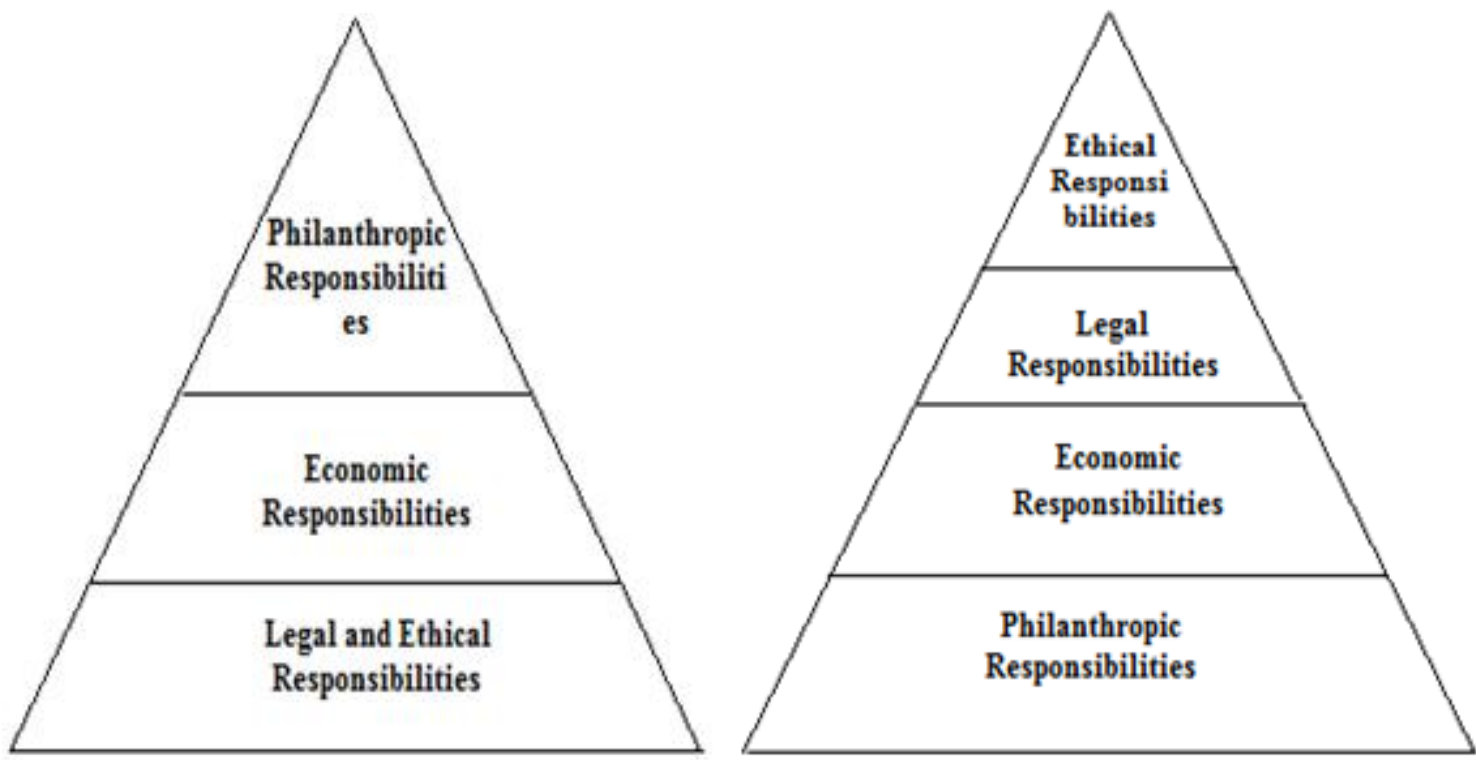

CSR model from managers in charge of logging issues in English-speaking and French-speaking zones

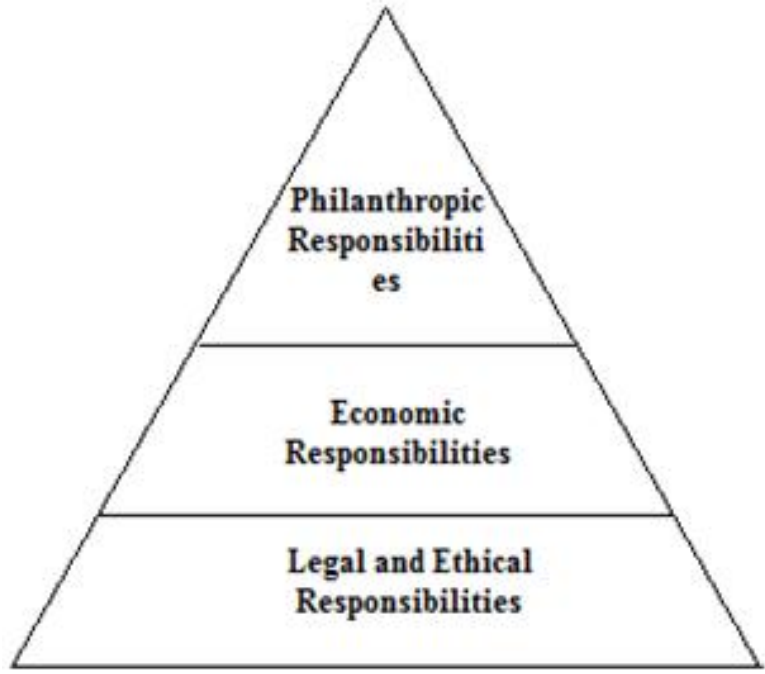

Figure2 to 8: Perceived Variations of Carroll's model in the Cameroonian logging sector

Table4: Synthesis of similarities and differences in stakeholders' perceptions

\begin{tabular}{|c|c|c|}
\hline Actors & Perceptions' Similarities & Perceptions' Differences \\
\hline Managers & $\begin{array}{l}\text { Preeminence is given to the } \\
\text { economic aspect. In fact, economic } \\
\text { responsibility is the foundation on } \\
\text { which other types of } \\
\text { responsibilities are based in these } \\
\text { two companies. }\end{array}$ & $\begin{array}{l}\text { At Beta, Carroll's model is reduced to three } \\
\text { levels because legal and ethical aspects are } \\
\text { considered to be linked. } \\
\text { Legal and ethical responsibilities are a priority } \\
\text { at Beta; they are at the base of the pyramid } \\
\text { unlike the Alpha company where priority is } \\
\text { given to the philanthropic responsibility at the } \\
\text { base of the pyramid. Although different from } \\
\text { Carroll's model, (the hierarchy of dimensions } \\
\text { different from those of Carroll's model) this } \\
\text { model remains four-dimensional at Alpha. }\end{array}$ \\
\hline Employees & $\begin{array}{l}\text { The ethical and legal aspects are } \\
\text { linked, thus reducing the pyramid } \\
\text { proposed by Carroll at three levels. } \\
\text { Economic responsibility is at the } \\
\text { second level of the hierarchy in } \\
\text { their order of priority. }\end{array}$ & $\begin{array}{l}\text { The preeminence order of responsibilities of } \\
\text { the model is different. } \\
\text { Ethical and legal aspects come third in Alpha's } \\
\text { preferences. On the other hand, in Beta, they } \\
\text { are at the base of the pyramid. The } \\
\text { philanthropic responsibility is at the base of } \\
\text { the pyramid for Alpha company. This }\end{array}$ \\
\hline
\end{tabular}




\begin{tabular}{|c|c|c|}
\hline & & $\begin{array}{l}\text { philanthropic responsibility is a priority for } \\
\text { Alpha employees, but not the case at Beta } \\
\text { where this aspect comes third in the order of } \\
\text { priorities. }\end{array}$ \\
\hline $\begin{array}{l}\text { Local and riparian } \\
\text { Communities }\end{array}$ & $\begin{array}{l}\text { The economic component comes } \\
\text { second in priorities; this } \\
\text { responsibility is at the second level } \\
\text { of the pyramid. }\end{array}$ & $\begin{array}{l}\text { The model is reduced to three levels at BETA } \\
\text { (the legal and ethical responsibilities are } \\
\text { considered as linked), while it remains at four } \\
\text { levels for the Alpha company. The hierarchy of } \\
\text { dimensions differs according to the local and } \\
\text { neighboring communities from one company to } \\
\text { another. At BETA, legal and ethical } \\
\text { responsibilities are the foundation on which } \\
\text { other types of responsibilities lie. Unlike the } \\
\text { Alpha company where the philanthropic } \\
\text { responsibility is at the base of the pyramid and } \\
\text { on which the economic, legal and ethical } \\
\text { responsibilities are based respectively. }\end{array}$ \\
\hline $\begin{array}{l}\text { Logging } \\
\text { Administration }\end{array}$ & $\begin{array}{l}\text { The proposed model, although } \\
\text { different from that of Carroll, is the } \\
\text { same in both the English-speaking } \\
\text { and French-speaking cultures. } \\
\text { Unlike Carroll's model, this one is } \\
\text { reduced to three levels, and the } \\
\text { legal and ethical responsibility } \\
\text { considered as linked represents the } \\
\text { foundation of the pyramid on which } \\
\text { economic and philanthropic } \\
\text { responsibilities are based. }\end{array}$ & \\
\hline
\end{tabular}

\section{DISCUSSION OF FINDINGS}

\subsection{Carroll's Model (1979): A Context-Contingent Model}

According to the perception degree of actors interviewed with regard to CSR policies, we were able to identify seven variants of the CSR model in the Cameroonian logging sector. In general, we make three observations. Firstly, we noticed with regard to BETA (located in the English-speaking part of Cameroon) that the legal and ethical responsibilities are considered as linked and constitute the base on which other types of responsibilities are found. Secondly, it emerges from this empirical study that as concerns the ALPHA company (located in a Cameroonian zone of French-speaking culture), the philanthropic responsibility is at the base of the pyramid on which other types of responsibilities depend. Thirdly and lastly, we note that the perceptions of those in charge of the logging administration with regard to CSR are identical in the two logging studied fields.

If the third observation seems to be obvious for the simple reason that the same logging administration operates from one logging zone to another, it is not the case for the first two observations. These findings are based on the colonial history in Cameroon. Indeed, having undergone several colonizations, particularly the German, the British and the French, populations underwent several approaches. In the Cameroonian Anglo-Saxon cultural zone, the colonist adopted the so-called "indirect rule" method which simply consisted in accompanying populations to preside over their own destiny. This seems to justify the fact that the legal and ethical responsibilities are more important in that part of the country. On the other hand, in the French-speaking zone, the colonist practiced the "direct rule" which consisted to the assimilation ofpopulations. This method relatedto paternalism consisted in keeping populations in a kind of dependency. This seems to justify the fact that in this part of the country, the philanthropic responsibility takes precedence over other responsibilities since populations are used to live in assistantship.

It thus emerges from these different variations which represent the empirical study results of the two cases studied that Carroll's model $(1979,1991)$ of CSR is contingent to the Cameroonian logging context. In addition, this model is adapted to each stakeholder interviewed in the Cameroonian logging sector. This investigation goes in line with those of Crane and Matten (2004), Visser (2005); 
Fadun (2014); Kwasi and Kwesi (2011); Golli and Yahioui (2009) and Zabin (2013) as far as the relativity of Carroll's model $(1979,1991)$ is concerned. In addition, the comparative analysis highlighted points of similarity and dissimilarities between the stakeholders' perceptions of companies located in the Anglo-Saxon cultural zone and French-speaking cultural zone respectively. We note that these findings are singular in the logging context in the Congo Basin in general and Cameroonin particularly.

\section{CONCLUSION, LIMITATIONS AND FUTURE RESEARCH AVENUES}

This research is of both theoretical and managerial interest. On the theoretical level, this work attempted to overcome a notorious theoretical lack of CSR by mobilizing specific contexts on CSR in an African country where it appears more like a constraint. Empirical studies highlighted the hierarchy of dimensions different from those of Carroll's original model. In addition, this work issued research proposals likely to contribute to the development of prospects for future research, particularly in the Congo Basin logging industry sector in general and specifically in Cameroon.

From the managerial view point, this research helps to highlight CSR practices in the Congo Basin logging sector, particularly in Cameroon, and recommends some ways to improve the adoption of a new CSR approach both for executives and employees, local and riparian communities as well as Cameroonian institutions in charge of logging issues. This work, taking into account the cultural analysis (Jonhson, 1992) and the intercultural perspective of the management of organizations in African (MOA) (Tidjani and Kamdem, 2010) coupled with the contextual analysis framework of Pettigrew (1992), argues that cultural duality (French and English) in Cameroon has a significant impact on CSR stakeholder perceptions.

To answer our initial research question, we mainly focused on an empirical exploratory survey of stakeholders (managers, employees, local and riparian communities, administration in charge of logging issues) of two Cameroonian companies in the logging industry sector located in the AngloSaxon cultural zone (BETA) and the French-speaking cultural zone (ALPHA) respectively, both explicitly engaged in their FSC certification which according to Bakouma (2014) and Cerutti et al., (2014) is attached to CSR.

The comparative analysis highlighted the fact that the various responsibilities generally identified by Carroll $(1979,1991)$ are found in companies in the Cameroonian logging industry sector. However, it appears that their dimensions' hierarchy differs from that of Carroll's model. That's why; we strongly support the idea that if CSR is a common subject, practices are not necessarily the same in companies, given the diversity of motives, strategies and actors' perceptions. The philanthropic component generally prevails on the economic, legal and ethical aspects, as far as the company located in the French-speaking cultural part of the country is concerned. On the other hand, in the BETA Company established in the Anglo-Saxon cultural zone, the legal and ethical dimensions (which are linked according to actors) are considered as being a priority for actors interviewed. In most cases, Carroll's model is reduced to three levels in English-speaking areas, while it remains at four levels in the French-speaking part of the country, although the preeminence order of responsibilities being different from Carroll's original model. If the managers of these two companies are of the opinion that economic responsibility is their leitmotiv and therefore overrides all other types of responsibilities, it is not the case for the priority order in other forms of responsibility. This also goes with employees and local and riparian communities as concerns the two companies studied. At BETA, stakeholders are more attached to legal and ethical values, unlike ALPHA where they are more sensitive to philanthropy and assistantship.

It should be noted that our conclusions are both preliminary and specific, and this necessarily limits the external validity of the results obtained. This limitation is undoubtedly inherent to the exploratory nature of this study, coupled with the method adopted and the fact that we have obscured some variables such as the profile of managers and actors interviewed. We have therefore simply compared the results obtained with previous research and not with their generalization. Further research with a statistically representative sample will certainly help to strengthen the scope of our findings. In addition, multivariate analyzes will, among others, confirm or refute the findings obtained from this exploratory research. Moreover, a comparison including other international contexts or the CentralAfrica sub-region could lead to interesting results. 


\section{REFERENCES}

[1] Aupperle K. E, Carroll A. B and Hatfield, J. D. (1985). An empirical examination of the relationship between corporate social responsibility and profitability. Academy of management Journal, vol. 28, no.2, p.446-463.

[2] Beaupré, D., Cloutier, J., Gendron, C., Jiménez, A., \& Morin, D. (2008). Gestion des ressources humaines, développement durable et responsabilité sociale. Revue internationale de psychosociologie, vol.14, no.33, p.77-140.

[3] Berger-Douce S. (2011). Le développement durable, un levier d'innovation pour les PME ? Revue française de gestion, vol.6, p.147-166.

[4] Bonneveux E et Saulquin J. Y. (2009). L'appropriation de la RSE par les dirigeants de PME. Le réseau comme vecteur de l'apprentissage managérial. Management \& Avenir, vol.3, p.170-186.

[5] Carroll A. (1991). «The pyramid of Corporate Social Responsibility: toward the moral management of organizational stakeholders », Business Horizons, July/august, pp.39-48.

[6] Castelo Branco M and Lima Rodriques L. (2007). Positioning stakeholder theory within the debate on corporate social responsibility. EJBO-Electronic Journal of Business Ethics and Organization Studies.

[7] Clarkson M. E. (1995). A stakeholder framework for analyzing and evaluating corporate social performance. Academy of management review, vol.20, no.1, p.92-117.

[8] Collerette, P. (1997). L'étude de cas au service de la recherche. Recherche en soins infirmiers, no.50, p.81-88.

[9] Commenne V, Champion E., Gendron C, Ramaswany R, Munoz I et Atidegla, A. (2006). Responsabilité sociale et environnementale des acteurs économiques. Mode d'emploi pour plus d'éthique et de développement durable.

[10] Crane A, Matten D and Moon J. (2004). Stakeholders as citizens? Rethinking rights, participation, and democracy. Journal of Business Ethics, vol.53, no.1, p.107-122.

[11] Elouidani A et Zoubir F. (2016). Quand un label en responsabilité sociétale de l'entreprise crée la valeur pour l'actionnaire dans un pays en développement: le cas marocain. Revue camerounaise de management, no.32, p.1-17.

[12] Freeman, R.C. (1984). «Strategic management: A Stakeholder Approach», Boston, Pitman.

[13] Friedman. M. (1970). «The Social Responsibility of Business is to Increase profits». The New-York Times Magazine. Septemberno.13. p. 11.

[14] Gagnon C. (2008). Arrimage des pratiques éducatives d'enseignants et de formateurs en entreprises en contexte d'attenance. Etudes de cas en formation professionnelle agricole.

[15] Gendre-Aegerter D. (2008). La perception du dirigeant de PME de sa responsabilité sociale: une approche par la cartographie cognitive (Doctoral dissertation, Université de Fribourg (Suisse).

[16] Golli A et Yahiaoui D. (2009). «Responsabilité sociale des entreprises: analyse du modèle de Carroll (1991) et application au cas Tunisien », Management \& Avenir, $\mathrm{n}^{\mathrm{0}}$ 23, p.139-152. DOI: 10.3917/ mav. 023.0139.

[17] Gond J.P. et S.A Mullenbach (2004), «Les fondements théoriques de la responsabilité sociale de l'entreprise», Revue dessciences de Gestion, $N^{\circ} 205$, janvier février, pp93-116.

[18] Johnson, G. (1992). Managing strategic change strategy, culture and action. Long range planning, vol.25, no. 1, p. 28-36.

[19] Jones T. M. (1980). Corporate social responsibility revisited, redefined. California management review, vol.22, no.3, p.59-67.

[20] Laarraf Z, Gandja S. V et Tchankam, J. P. (2015). RSE et PME: éclairage par la théorie des parties prenantes à partir de la grille de Mitchell, Agle et wood. Gestion 2000, vol.32, no1, p.35-53.

[21] Lantos G. P. (2001). The boundaries of strategic corporate social responsibility. Journal of consumer marketing, vol.18, no7, p.595-632.

[22] Mamboundou, J. P. (2016). De la gestion de l'information RH à la gestion de la citoyenneté organisationnelle $(\mathrm{CO})$ : pratiques managériales et réactions des salariés dans les entreprises gabonaises. Question ( $s$ ) de management, no.1, p.45-60.

[23] Mercier S. (2004). L'éthique dans les entreprises (No. hal-00156446).

[24] Miles M. B and Huberman, A. M. (1991). Analyse des données qualitatives: recueil de nouvelles méthodes. De Boeck et Larcier.

[25] Mitchell R. K, Agle B. R et Wood D. J. (1997). Toward a theory of stakeholder identification and salience: Defining the principle of who and what really counts. Academy of management review, vol.22, no.4, p.853-886.

[26] Mullenbach-Servayre A. (2007). L'apport de la théorie des parties prenantes à la modélisation de la responsabilité sociétale des entreprises. La revue des Sciences de Gestion, no.1, p.109-120. 
CSR Practices in Africa: A Comparative Analysis of the Carroll's Model Between Logging Companies in the Anglo-Saxon and French-Speaking Cultural Zones of Cameroon

[27] Ndoumbe Berock. I.B. (2017).Construction de la responsabilité sociétale des entreprises (RSE) dans les pays en développement: une application dans les entreprises d'exploitations forestières au Cameroun. Thèse de doctorat soutenue publiquement à l'Université de Strasbourg.

[28] Ndoumbe Berock. I.B, et al., « Les pratiques de la RSE par les entreprises d'exploitations forestières dans le Bassin du Congo : conformisme ou volontarisme?», Revue de l'organisation responsable 2016 vol. 11, no.2, p. 55-63. DOI 10.3917/ror.112.0055.

[29] Ngok-Evina, J-F., (2014), La compétitivité des entreprises africaines : le cas du Cameroun, Revue des Sciences de Gestion, vol.3, no. (267-268), p.51-58.

[30] Nkakleu R. (2016). Les pratiques de GRH des PME africaines sont-elles toujours informelles? Une analyse contextualiste. Question ( $s$ ) de management, no.1, p.83-104.

[31] Pettigrew, A. M. (1992). The character and significance of strategy process research. Strategic management journal, vol.13, no.2, p.5-16.

[32] Porter M. E and Kramer M. R. (2007). The Link Between Competitive Advantage and Corporate Social Responsibility. Harvard business review.

[33] Quazi A. M and O'brien, D. (2000). An empirical test of a cross-national model of corporate social responsibility. Journal of business ethics, vol.25, no.1, p.33-51.

[34] Rowley T. J. (1997). Moving beyond dyadic ties: A network theory of stakeholder influences. Academy of management Review, vol.22, no.4, p.887-910.

[35] Schäfer H. (2016). Chemical transport reactions. Elsevier.

[36] Sethi S. P. (1975). Dimensions of corporate social performance: An analytical framework. California management review, vol.17, no.3, p. 58-64.

[37] Sharma S. (2001). L'organisation durable et ses stakeholders. Revue française de gestion, p.154-167.

[38] Tidjani B., Kamdem E. (2010). Gérer les ressources humaines en Afrique, Paris, EMS.

[39] Valor C. (2005). Corporate social responsibility and corporate citizenship: Towards corporate accountability. Business and society review, vol.110, no.2, p.191-212.

[40] Visser W. (2006). Revisiting Carroll's CSR pyramid. Corporate citizenship in developing countries, p.29-56.

[41] Yin R. K. (1994). «Case Study Research. Design and Methods», Thousand Oaks, Sage Publications, 171 p.

\section{AUTHOR's BIOGRAPHY}

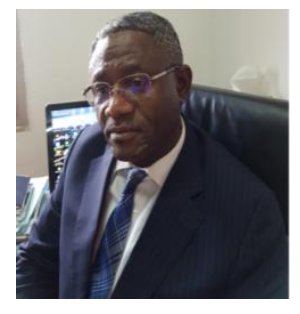

Dr. Georges WANDJI is a Lecturer-researcher and assistant professor at the Faculty of Economics and Management (FSEG) of the University of Dschang in Cameroon. He is also Director of the Center of Expertise and Consulting in Business Management (CEGEC SARL) whose head office is based in Yaounde, which provides training for many young Africans, especially Cameroonians for more than twenty five years. Her research focuses on Corporate Governance with strong sensitivities in finance and accounting organization. Dr. WANDJI has also served for nearly ten years as the head of the FSEG accounting department.

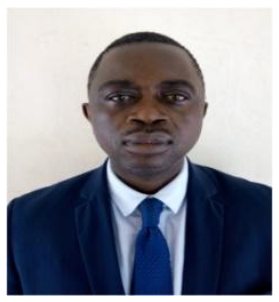

Isaac Bernard NDOUMBE BEROCK is a Lecturer-researcher and assistant professor in the Department of Human Resources Management (HRM) of the Higher School of Economics and Commerce (ESSEC) of the University of Douala in Cameroon. His research focuses on forest governance in the Congo Basin, with a strong sensitivity to Corporate Social Responsibility (CSR), Sustainable Development, Managerial Ethics and Managerial Innovation. Expert in Management and Strategy of Organizations, Dr. Isaac Bernard NDOUMBE BEROCK is also consultant in many logging companies in Central Africa.

Citation: Georges WANDJI, Isaac Bernard NDOUMBE BEROCK. "CSR Practices in Africa: A Comparative Analysis of the Carroll's Model Between Logging Companies in the Anglo-Saxon and FrenchSpeaking Cultural Zones of Cameroon" International Journal of Managerial Studies and Research (IJMSR), vol 6, no.8, 2018, pp. 60-73. doi: http://dx.doi.org/10.20431/2349-0349.0608007.

Copyright: (C) 2018 Authors. This is an open-access article distributed under the terms of the Creative Commons Attribution License, which permits unrestricted use, distribution, and reproduction in any medium, provided the original author and source are credited. 